\title{
DISCURSO DE APRESENTAÇÃO DA ENFERMEIRA DO ANO
}

Clarice Ferrarini *

Este nosso encontro é na cidade de povo heróico, orgulhoso de suas lutas pela reconquista do território brasileiro, então sob o domínio dos holandeses; povo amante de sua terra, que fez valer a sua vontade de ser livre nas lutas pela independência já em 1817 e que deu, a um de seus próprios filhos, tombado pela democracia, c. nome de sua Capital - João Pessoa.

No ponto mais afastado da costa leste do País, a Divisão Hospitalar da Johnson \& Jhnson e a Associação Brasileira de Enfermagem, vem homenagear uma figura "heróica" da enfermagem brasileira, que recebe o título de Enfermeira do Ano 1972.

Dr. ${ }^{a}$ Haydée tem dedicado quase todo, senão todo o seu tempo ¿̀ causa da enfermagem brasileira. Fez, até hoje, pela Enfermagem e pelas enfermeiras mais do que se poderia esperar de um profissional eficiente. Dotada de imensa capacidade de antevisão, trabalho e decisão, aliado a um espírito de humildade, em todas as cportunidades que lhe foram permitidas, sempre procurou a melhor solução para os problemas que a profissão defrontava, jamais, deixando de considerar todos que nela trabalhavam.

Apresentar Dra. Haydeé Guanais Dourado é tarefa bastante complexa: apresentarr às colegas é tarefa simples, é só reavivar fatos conhecidos - todas a conhecem e dedicam amizade, carinho, reconhecimento e gratidão pelo seu valor prfissional, admirando sua inteligência aplicada à causa da Enfermagem. Apresentar àqueles que não a conhecem é tarefa muito difícil ,pois, na maneira resumida de relatar, seria imperdoável falhas ou omissões das grancies realizações e qualidades dessa lider. Ao lado da complexidade da apresentação, é para mim, uma das mais agradáveis incumbências enum€rar suscintamente fatos e realizações da colega que estimo, admiro e respeito.

Haydeé nasceu na Bahia de tradições, na cidade do Morro do Chapéu, às margens do lendário e brasileiro Rio São Francisco.

* Secretária Executiva da ABEn. 
Em Ircê fez o curso primário e em Itacira o secundário, no Instituto de Ponte Nova. Decidindo-se pela enfermagem, concluiu, na Escola Ana Neri, em 1935, o curso, recebendo o Diploma de Enfermeira.

Em 1941/42, fez, em Toronto, Canadá. Curso de Supervisão e Pedagogia e Didática de Enfermagem e na Escola de Sociologia e Política de São Paulo fez Ciências Políticas e Sociais em 1945. E, em 1953, completou o curso de Jornalismo na Faculdade Normal de Filosofia no Rio de Janeiro.

Fez curso de extensão "International on the Planning on Nursing Studies" em Sevres, França, em 1956.

Recebeu bolsa de estudos do Ministério de Educação e Saúde para os Estados Unidos em 1941; da Fundação Rockfeller para o Canadá em 1955 e da Fundação Rockfeller, para a França em 1956.

É Bacharel em Ciências Políticas e Sociais, Bacharel em Jornalismo, Doutor em Enfermagem pela Universidade Federal do Rio de Janeiro e Livre Docente (Ética e História da Enfermagem) pela Universidade Federal do Rio de Janeiro.

Recebeu da Associação Brasileira de Enfermagem o Título de Sócio Honorário, pelos relevantes serviços prestados à enfermagem nacional, em 1971.

Trabalhou como Enfermeira Adjunta no Ministério de Educação e Saúde de 1935/65 e Enfermeira do M.E.C. de 1965/68. Foi Instrutora da Escola de Enfermagem São Paulo no período de 1943/46. onde foi Regente da disciplina de Fundamento de Enfermagem, Membro do Conselho Administrativo e Coordenadora do curriculum de ciências básicas da Escola de Enfermagem São Paulo.

Diretora da Escola de Enfermagem da Bahia de 1946/49, onde foi Regente da disciplina de Ajustamento Profissional; Ética de Enfermagem, - História de Enfermagem, Introdução à Saúde Pública, Higiene e Saúde Pública, Sociologia, Higiene Mental e 1.a Coordenadora do Curriculum do Curso de Graduação.

No Serviço Nacional de Tuberculose como Enfermeira Chefe de 1951/53.

Foi Diretora do Centro de Levantamento de Recursos e Necessidades de Enfermagem no Brasil, patrocinado pela ABEn em 1958.

No Hospital Distrital de Brasília e Universidade de Brasília como consultora em enfermagem em 1960. M.E.C. - Divisão de Ensino Superior, como Diretora Representante, em 1965/68 e como Consultora e Inspetora de 1966/68. Desde 1969 trabalha como Supervisora no Serviço de Enfermagem do Hospital Distrital de Brasília.

Participou em bancas de exames de seleção, atuou como especialista em Legislação em Seminários e participou de diversas Bancas Examinadoras para Defesa de Tese. 
Esteve presente em 19 Congresso Brasileiros de Enfermagem, Congresos Internacionais. Congresso de Hospitais, Brasileiro de Serviço Social, Educação em Enfermagem e de Higiene.

Ministrou cursos de visitadoras nos Estados do Norte.

Responsável pelo ensino de Ética de Enfermagem, curso de aperfciçoamento para enfermeiras na Secretaria de Saúde da Guanabara em 1962.

Professora visitante contratada de História, na Universidade Federal de Pernambuco e Bahia em 1962.

Elaborou relatório sobre ensino de enfermagem na Paraíba. É Membro da Associação de Ex-Alunos da Universidade de Toronto e da Escola Ana Neri. É membro da Sociedade de Higiene e do Sindicato de Jornalistas Profissionais. Membro ativo da ABEn desde 1945. É Diretora Redatora Chefe da Revista Brasileira de Enfermagem, tendo cerca de 70 Editoriais, de grande valor para a profissão. Foi incansável durante 20 anos que coordenou a Comissão de Legislação da ABEn.

Difícil enumerar a sua atuação na Comissão; recentemente, vimos aprovado o Conselho Federal de Enfermagem, seguido por Dra. Haydeé por mais de 11 anos. Tem cerca de 100 artigos publicados em Revistas Científicas do País e estrangeiro, além de livretos e traduções feitas. As enfermeiras da Seção da Bahia, São Paulo, Minas Gerais, Pernambuco, Paraíba e Maranhão apresentaram Dra. Haydeé como candidata ao Premio Enfermeira do Ano 1972, porque consideram-na como uma das autênticas líderes da enfermagem do Brasil.

Haydeé nunca foi estranha aos chamados da solidariedade humana, entregou-se, sempre, e em todas as facetas de sua vida, à icientificação das necessidades e dos sofrimento do seu semelhante.

Pensando no próximo, e afeiçoada sempre a ele, a sua riqueza de alma incentivou suas forças todas para a tarefa do estudo e da pesquisa, como condições de aprimoramento à formação da melhor enfermeira.

Sem concessões ao comodismo ou ao alheamento, e mesmo deisando prøocupaçōes materiais, aquela que sentia jorrar, da madrugada ao último momento da labuta diária da enfermeira, o impulso continvado para o bem servir, foi juntando, ano a ano, parcelas do conhecimento profissional e da experiência, até construir, com o significado de edifício de amor e trabalho, o momento que vive hoje, e que pərmite seja, por nós, também vivido.

Aquiesceu em vir aqui, à nossa frente, para ouvir a sonata do agradecimento, para participar da festa que seus amigos, e assim são todos que a conhec-m, emocionados vivem, e vivem sem a impressão de estarem presenciando o término de uma fase na vida 
de bondosa enfermeira mas com a convicção de que ofertam muitos de nós, ousadas até pois podemos ferir quem é modesta um título que era já conseguido pelos anos de trabalho, de dedicação, de carinho, anos aparentemente perdidos no tempo, mas, na verdade, perenes nos corações de tantos que, mesmo anônimos, sentiram um dia, em um momento de dor, o calor da leve presença, sempre vindo com o aroma do amparo e da esperança.

Não é um momento de despedida. Por isso, nossas mãos não pesam em sinal de adeus. É a festa de identificação de um símbolo, da mulher que escreveu - no silêncio, extenuada quantas vezes - a estória da melhor disposição e da entrega. É a festa da indenização da mulher que, mostrando o que realizou, formula um convite para os que estão iniciando; é a festa, que deve ser alegre, para quem, vivendo para os outros e para sua Pátria, viveu com a mensagem de Cristo, indiferente por pagas, toda exclusiva no bem servir.

Aqui as colegas dos mais distantes pontos do País reverenciam a figura da Mulher-Enfermeira. 